\title{
A divergent strain of melon chlorotic spot virus isolated from black medic (Medicago lupulina) in Austria
}

\author{
Yahya Z. A. Gaafar ${ }^{1} \mathbb{B}$, Katja R. Richert-Pöggeler ${ }^{1}$ (D), Angelika Sieg-Müller ${ }^{1}$, Petra Lüddecke ${ }^{1}$, Kerstin Herz ${ }^{1}$, \\ Jonas Hartrick', Yvonne Seide ${ }^{1}$, Heinrich-Josef Vetten ${ }^{2}$ and Heiko Ziebell ${ }^{1 *}$ (D)
}

\begin{abstract}
A tenuivirus, referred to here as JKI 29327, was isolated from a black medic (Medicago lupulina) plant collected in Austria. The virus was mechanically transmitted to Nicotiana benthamiana, M. Iupulina, M. sativa, Pisum sativum and Vicia faba. The complete genome was determined by high throughput sequencing. The genome of JKI 29327 consists of eight RNA segments closely related to those of melon chlorotic spot virus (MeCSV) isolate E11-018 from France. Since segments RNA 7 and 8 of JKI 29327 are shorter, its genome is slightly smaller (by 247 nts) than that of E11-018. Pairwise comparisons between the predicted virus proteins of JKI 29327 and their homologues in E11-018 showed aa identities ranging from 80.6 to 97.2\%. Plants infected with E11-081 gave intermediate DAS-ELISA reactions with polyclonal antibodies to JKI 29327. Since JKI 29327 and E11-018 appear to be closely related both serologically and genetically, we propose to regard JKI 29327 as the black medic strain of MeCSV. To our knowledge, JKI 29327 represents the second tenuivirus identified from a dicotyledonous plant. Serological and molecular diagnostic methods were developed for future detection.
\end{abstract}

Keywords: High throughput sequencing, Melon chlorotic spot virus, Segmented virus, Medicago sativa, Pisum sativum, Vicia faba

\section{Main text}

Members of the genus Tenuivirus, family Phenuiviridae, are plant viruses that possess non-enveloped filamentous particles and a genome consisting of four to eight singlestranded RNA segments with negative or ambisense polarity. The thin filamentous particles consist of ribonucleoprotein (RNP) complexes, measuring $3-10 \mathrm{~nm}$ in diameter and with lengths proportional to the sizes of the RNAs they contain. Based on the RNA sizes, the particles may appear as small, large or even branched circles $[1,2]$. Tenuivirus RNAs are neither capped at their $5^{\prime}$ end nor polyadenylated at the $3^{\prime}$ end. The nucleotide sequences of the $5^{\prime}$ and $3^{\prime}$ ends of each segment are complementary [1]. Tenuiviruses are known to be transmitted by planthoppers or by mechanical means albeit with difficulty [1]. According to the International

\footnotetext{
* Correspondence: heiko.ziebell@julius-kuehn.de

1 Julius Kühn Institute, Institute for Epidemiology and Pathogen Diagnostics, Messeweg 11-12, 38104 Braunschweig, Germany

Full list of author information is available at the end of the article
}

Committee on Taxonomy of Viruses (ICTV), seven virus species are currently assigned to the genus Tenuivirus: Echinochloa hoja blanca virus (EHBV), Iranian wheat stripe virus (IWSV), Maize stripe virus (MSpV), Rice grassy stunt virus (RGSV), Rice hoja blanca virus (RHBV), Rice stripe virus (RSV) and Urochloa hoja blanca virus (UHBV). In addition, three more species have been proposed and are pending recognition by ICTV: melon chlorotic spot virus (MeCSV), Ramu stunt virus (RmSV) and wheat yellow head virus (WYHV) [24]. The natural host range of tenuiviruses is typically restricted to monocots of the Poaceae family causing yield losses in important food crops such as rice (Oryza sativa L.) and maize (Zea mays L.) [5]. The recent identification of MeCSV from melon (Cucumis melo) in France represents the first report of a tenuivirus naturally infecting a dicotyledonous plant [2].

In 2011, a black medic (Medicago lupulina L.) plant showing virus-like symptoms was collected in StadlPaura, Austria, but the symptoms were not recorded at

(c) The Author(s). 2019 Open Access This article is distributed under the terms of the Creative Commons Attribution 4.0 International License (http://creativecommons.org/licenses/by/4.0/), which permits unrestricted use, distribution, and reproduction in any medium, provided you give appropriate credit to the original author(s) and the source, provide a link to the Creative Commons license, and indicate if changes were made. The Creative Commons Public Domain Dedication waiver (http://creativecommons.org/publicdomain/zero/1.0/) applies to the data made available in this article, unless otherwise stated. 
the time. The sample was sent to Julius Kuehn Institute for analysis. Electron microscopy revealed the presence of RNP that appeared to resemble disassembled rhabdovirus particles $[6,7]$. However, polyclonal antibodies JKI1607 raised against alfalfa-associated nucleorhabdovirus (AaNV) [7] failed to react with this virus in DAS-ELISA. The virus was transmitted mechanically as described in [7] to Nicotiana benthamiana, M. lupulina, M. sativa, Pisum sativum and Vicia faba, and was referred to as JKI 29327. Three weeks post inoculation, $N$. benthamiana plants showed systemic mottling, slight vein clearing and top leaf curling, whilst $M$. lupulina and $M$. sativa plants showed systemic vein clearing. P. sativum plants showed systemic vein clearing and severe yellowing and Vicia faba showed systemic mottling, yellowing and leaf rolling (Fig. 1). The virus particles of JKI 29327 were partially purified from infected $N$. benthamiana and used for antiserum production as described before [7]. The antibodies (JKI-1608) were used for DAS-ELISA analysis of sap-inoculated plants and confirmed infection of symptomatic plants.

For determination of the complete genome sequence of JKI 29327, total RNA was extracted from infected $N$.
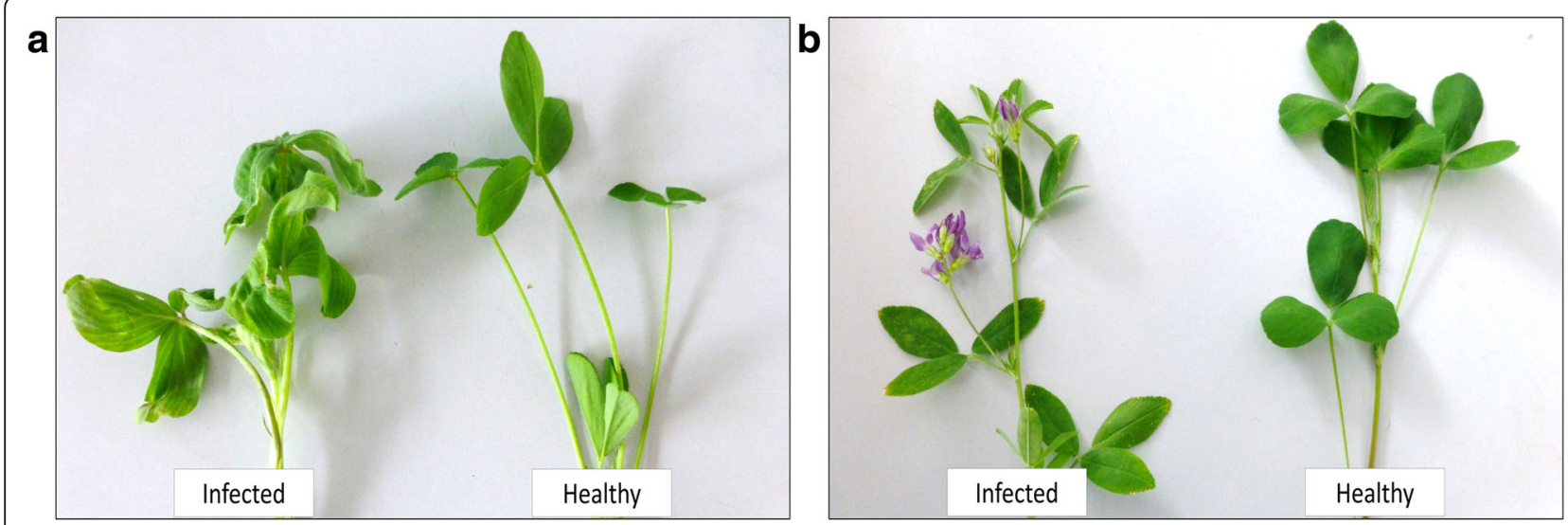

C

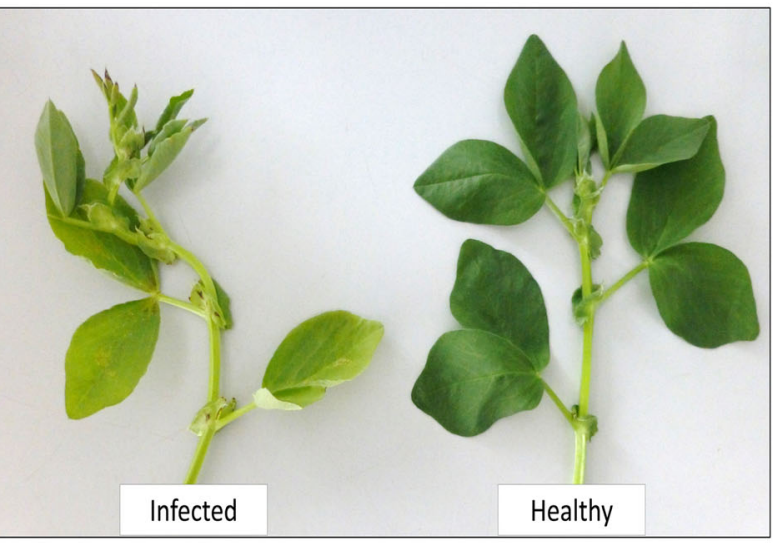

d

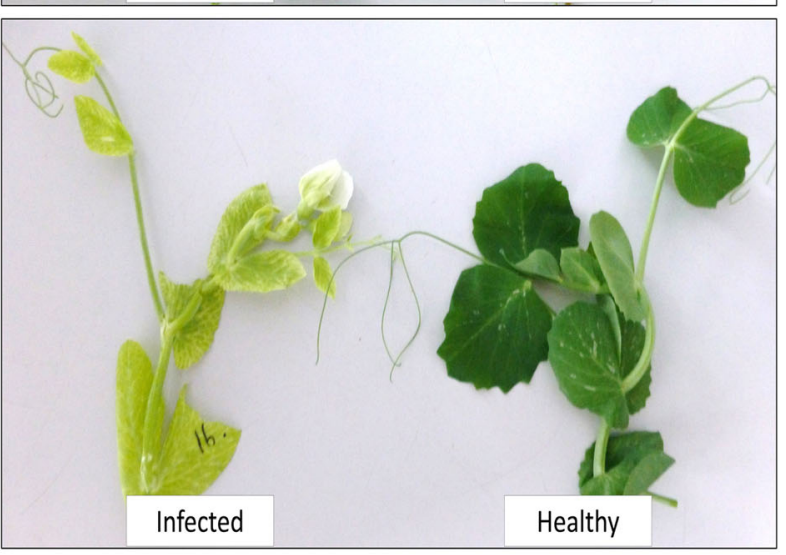

$\mathbf{e}$

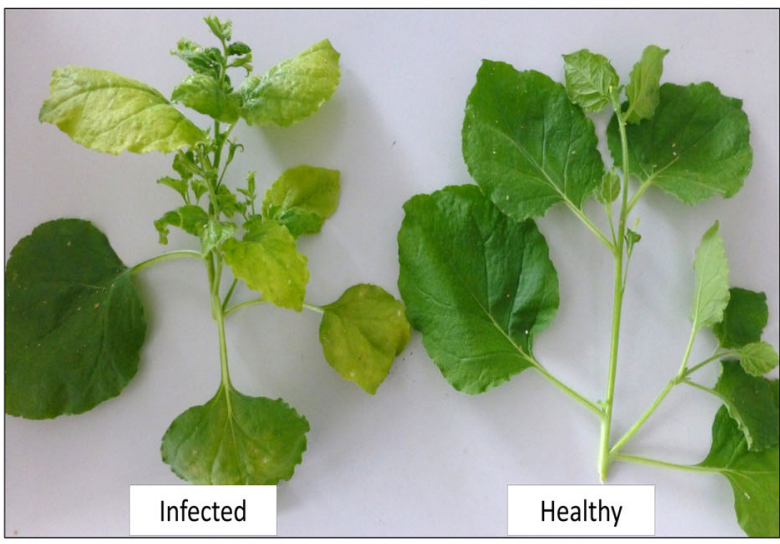

Fig. 1 Plants infected with the black medic tenuivirus (JKI 29327): (a) Medicago lupulina, (b) M. sativa, (c) Vicia faba, (d) Pisum sativum and (e) Nicotiana benthamiana 
benthamiana using innuPREP RNA Mini Kit (Analytik Jena AG) followed by ribosomal RNA depletion using the RiboMinus Plant kit (Invitrogen). The ribo-depleted RNA was used for high throughput sequencing (HTS) on a MiSeq (v3) platform $(2 \times 301)$ as described before [7]. A total of 2,056, 956 reads were obtained. The raw reads were quality trimmed and size filtered using Geneious Prime (v. 2019.0.3) (Biomatters Limited). The reads were then de novo assembled using Geneious assembler. A total of 53,651 contigs were generated and used for Blastn and Blastx search using virus/viroid databases on NCBI. Fifty-eight contigs shared nucleotide (nt) sequence identities (from 73.5 to $90.6 \%$ ) and amino acid (aa) sequence identities from 63.8 to $97.2 \%$ to $\mathrm{MeCSV}$. No other virus sequences were detected. The reference sequences of MeCSV (NC_040448 to NC_040455) were used to map the black medic tenuivirus sequences. The complete genome sequence of JKI 29327 (containing eight segments (Fig. 2a)) was assembled (19,805 nt; accession nos. MK450511 to MK450518) but segment RNA7 and RNA8 were $94 \mathrm{nt}$ and $177 \mathrm{nt}$ shorter than the genome of the isolate

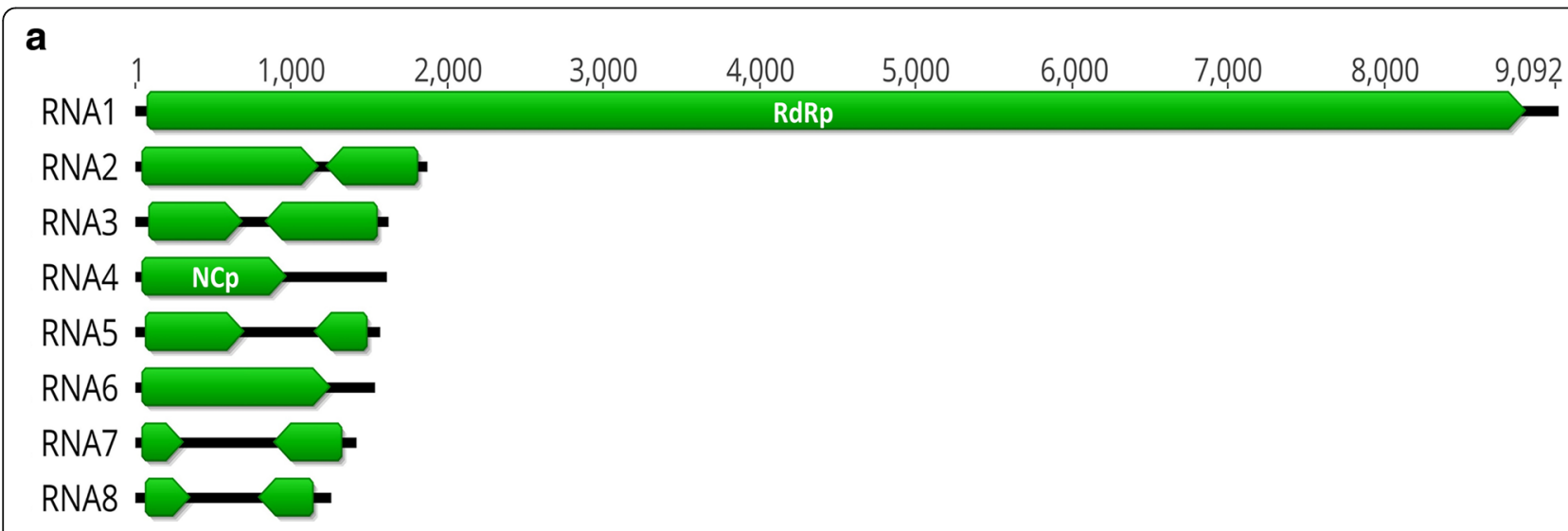

b

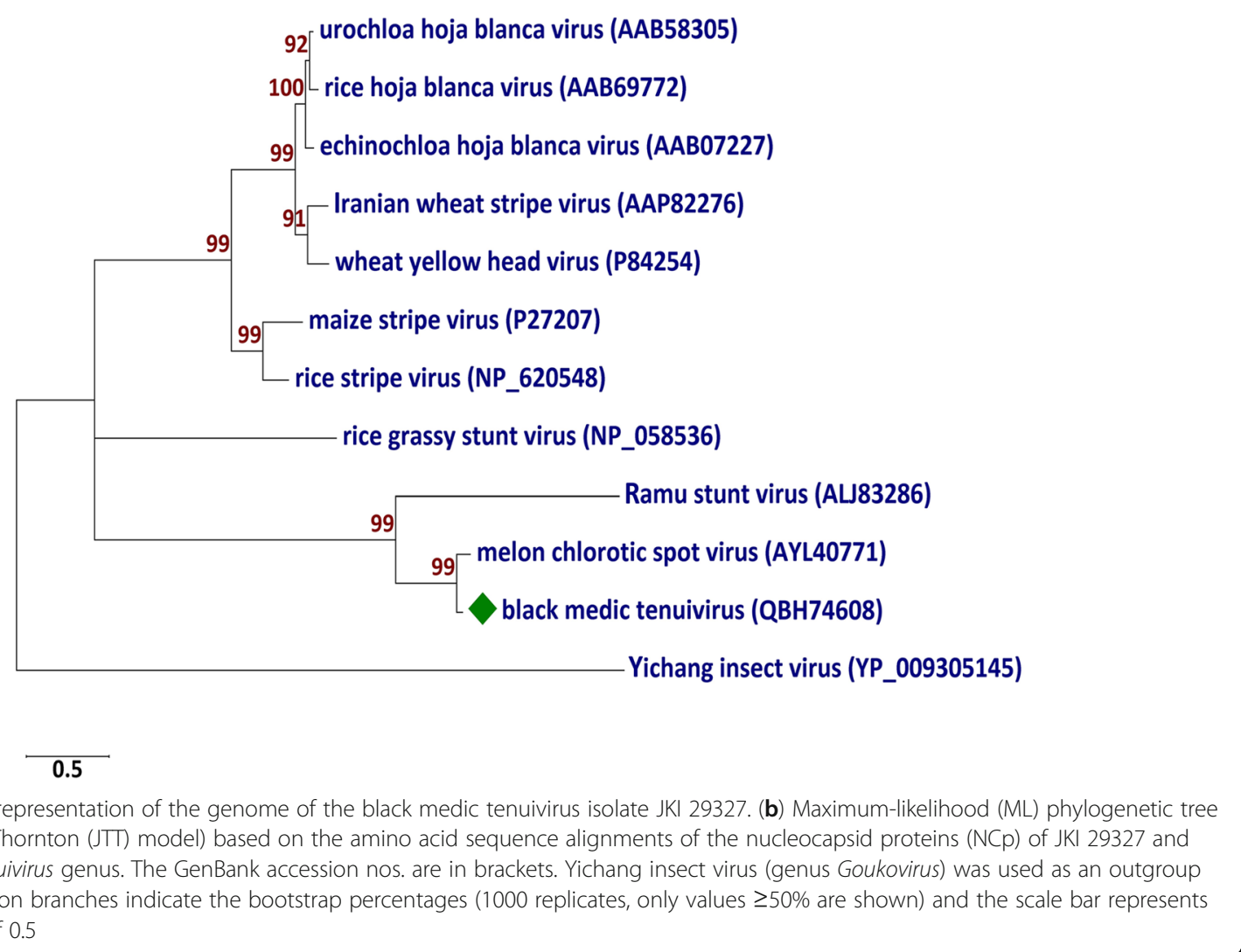

Fig. 2 (a) Graphical representation of the genome of the black medic tenuivirus isolate JKI 29327. (b) Maximum-likelihood (ML) phylogenetic tree (using Jones-Taylor-Thornton (JTT) model) based on the amino acid sequence alignments of the nucleocapsid proteins (NCp) of JKI 29327 and members of the Tenuivirus genus. The GenBank accession nos. are in brackets. Yichang insect virus (genus Goukovirus) was used as an outgroup sequence. Numbers on branches indicate the bootstrap percentages (1000 replicates, only values $\geq 50 \%$ are shown) and the scale bar represents a genetic distance of 0.5 
E11-018 of MeCSV. Analysis of each segment showed the presence of conserved nt sequences which can also be observed in other tenuiviruses (ACA CAA AGU C at the 5' end with its complementary sequence UGU GUU UCA G at the 3 ' end). Eight primers pairs were designed using Primer 3 (2.3.7) tool in Geneious (Table 1) to confirm the physical presence of all eight viral segments using RT-PCR (OneTaq One-Step RT-PCR Kit; NEB) [8] on fresh RNA extracts from $N$. benthamiana. The amplicons were gelpurified using Zymoclean Gel DNA Recovery Kit (Zymo Research) and Sanger sequenced; sequence analyses of these amplicons showed that they were $100 \%$ identical to the corresponding segment sequences obtained by the HTS analysis and thus confirmed the presence of each individual viral segment.

To predict the open reading frames' (ORF) functions, the translation of each ORF was used to search for conserved domains on NCBI's conserved domain database (CDD v 3.16) [9]. Only two ORFs matched with entries in the database, i.e., RNA1-ORF1 with Bunyavirus RNA-dependent RNA polymerase (accession no.: cl20265) and RNA4-ORF1 with Tenuivirus/Phlebovirus nucleocapsid protein (accession no.: cl05345) (Table 1). Pairwise alignments for the different regions of each segment of JKI 29327 were performed with

Table 1 The genome characteristics of melon chlorotic spot virus (MeCSV) isolate (JKI 29327) from Austria; nt and aa sequence identities of the 8 RNA segments compared to the respective homologous regions in the genome of MeCSV isolate E11-018 from France and the list of primers used for segment identification

\begin{tabular}{|c|c|c|c|c|c|c|c|c|c|c|c|}
\hline \multicolumn{5}{|c|}{ Genome segments } & \multicolumn{2}{|c|}{$\begin{array}{l}\text { Intergenic region } \\
(\mathrm{IR})\end{array}$} & \multicolumn{5}{|c|}{ Predicted proteins } \\
\hline \multirow[t]{2}{*}{ Type } & \multirow{2}{*}{$\begin{array}{l}\text { Length } \\
(\mathrm{nt})\end{array}$} & \multirow[b]{2}{*}{$\begin{array}{l}\text { Percent } \\
\text { nt } \\
\text { identity } \\
\text { to } \\
\text { MeCSV } \\
\text { E11- } \\
018\end{array}$} & \multicolumn{2}{|c|}{ PCR primers used for JKI 29327} & \multirow{2}{*}{$\begin{array}{l}\text { Length } \\
(\mathrm{nt})\end{array}$} & \multirow[b]{2}{*}{$\begin{array}{l}\text { Percent } \\
\text { nt } \\
\text { identity } \\
\text { to } \\
\text { MeCSV } \\
\text { E11- } \\
018\end{array}$} & \multirow[t]{2}{*}{ ORF } & \multirow[t]{2}{*}{ Putative functions } & \multirow{2}{*}{$\begin{array}{l}\text { Length } \\
\text { (aa) }\end{array}$} & \multirow{2}{*}{$\begin{array}{l}\text { Size } \\
(k D a)\end{array}$} & \multirow[b]{2}{*}{$\begin{array}{l}\text { Percent } \\
\text { aa } \\
\text { identity } \\
\text { to } \\
\text { MeCSV } \\
\text { E11- } \\
018\end{array}$} \\
\hline & & & Name & Sequence & & & & & & & \\
\hline \multirow[t]{2}{*}{ RNA1 } & 9092 & 82.4 & $\begin{array}{l}\mathrm{HZ}- \\
603\end{array}$ & $\begin{array}{l}\text { 5' ACA GAA GTG GAA TGG } \\
\text { GCT GG 3' }\end{array}$ & NA & NA & ORF1 & $\begin{array}{l}\text { RNA-dependent RNA } \\
\text { polymerase }\end{array}$ & 2940 & 340 & 92.1 \\
\hline & & & $\begin{array}{l}\mathrm{HZ}- \\
604\end{array}$ & $\begin{array}{l}5^{\prime} \text { GCA ACA CCC TCA TCA CTC } \\
\text { CA } 3^{\prime}\end{array}$ & & & & & & & \\
\hline \multirow[t]{2}{*}{ RNA2 } & 1847 & 84.6 & $\begin{array}{l}\mathrm{HZ}- \\
605\end{array}$ & $\begin{array}{l}\text { 5' AGC TCA GTA ACC GGA } \\
\text { ACT GC } 3^{\prime}\end{array}$ & 50 & 100 & ORF2a & no match & 373 & 43.6 & 87.7 \\
\hline & & & $\begin{array}{l}\mathrm{HZ}- \\
606\end{array}$ & $\begin{array}{l}5^{\prime} \text { CGC AAT AGC AGG GTC } \\
\text { CAG AT 3' }\end{array}$ & & & ORF2b & no match & 196 & 43.7 & 87.3 \\
\hline \multirow[t]{2}{*}{ RNA3 } & 1598 & 85.8 & $\begin{array}{l}\mathrm{HZ}- \\
607\end{array}$ & $\begin{array}{l}\text { 5' TGG TGC CAG AAG GAA } \\
\text { AGG AC } 3^{\prime}\end{array}$ & 157 & 72.6 & ORF3a & no match & 195 & 23.2 & 93.3 \\
\hline & & & $\begin{array}{l}\mathrm{HZ}- \\
608\end{array}$ & $\begin{array}{l}\text { 5' GGC AAT GCC TCA CAA } \\
\text { TCG TC } 3^{\prime}\end{array}$ & & & ORF3b & no match & 235 & 27.6 & 89.8 \\
\hline \multirow[t]{2}{*}{ RNA4 } & 1591 & 78.3 & $\begin{array}{l}\mathrm{HZ}- \\
609\end{array}$ & $\begin{array}{l}\text { 5' AAG TAA GGG CAG GCT } \\
\text { GAA CC } 3^{\prime}\end{array}$ & NA & NA & ORF4 & nucleocapsid protein & 305 & 33.6 & 88.2 \\
\hline & & & $\begin{array}{l}\mathrm{HZ}- \\
610\end{array}$ & $\begin{array}{l}\text { 5' AGG CTT TCT GCT AAG TGG } \\
\text { GC 3' }\end{array}$ & & & & & & & \\
\hline \multirow[t]{2}{*}{ RNA5 } & 1547 & 81.7 & $\begin{array}{l}\mathrm{HZ}- \\
611\end{array}$ & $\begin{array}{l}\text { 5' GAA CTG TAC CGC TGA TGG } \\
\text { GT 3' }\end{array}$ & 446 & 68.3 & ORF5a & no match & 210 & 23.2 & 93.3 \\
\hline & & & $\begin{array}{l}\mathrm{HZ}- \\
612\end{array}$ & $\begin{array}{l}\text { 5' CTT TGG TCT GGA GCT GTG } \\
\text { CT 3' }\end{array}$ & & & ORF5b & no match & 114 & 13 & 95.6 \\
\hline \multirow[t]{2}{*}{ RNA6 } & 1509 & 84.7 & $\begin{array}{l}\mathrm{HZ}- \\
613\end{array}$ & $\begin{array}{l}\text { 5' CGC ATC CTG AAT CCC ATC } \\
\text { TCT 3' }\end{array}$ & NA & NA & ORF6 & no match & 400 & 45.5 & 91.2 \\
\hline & & & $\begin{array}{l}\mathrm{HZ}- \\
614\end{array}$ & $\begin{array}{l}5^{\prime} \mathrm{GCT} \text { GGC ATC ACT AGA } \\
\text { CGG AT } 3^{\prime}\end{array}$ & & & & & & & \\
\hline \multirow[t]{2}{*}{ RNA7 } & 1392 & 73.2 & $\begin{array}{l}\mathrm{HZ}- \\
615\end{array}$ & $\begin{array}{l}\text { 5' ATC AGG TGT TAG CTG GCC } \\
\text { AC 3' }\end{array}$ & 586 & 55.6 & ORF7a & no match & 84 & 9.8 & 90.5 \\
\hline & & & $\begin{array}{l}\mathrm{HZ}- \\
616\end{array}$ & $\begin{array}{l}\text { 5' TAA CCA CCT TCC CTG CTG } \\
\text { TG } 3^{\prime}\end{array}$ & & & ORF7b & no match & 143 & 15.9 & 80.6 \\
\hline \multirow[t]{2}{*}{ RNA8 } & 1229 & 68.7 & $\begin{array}{l}\mathrm{HZ}- \\
617\end{array}$ & $\begin{array}{l}\text { 5' ACC CTA AGT GGA TCC } \\
\text { GAG GT 3' }\end{array}$ & 446 & 58.3 & ORF8a & no match & 93 & 10.9 & 94.8 \\
\hline & & & $\begin{array}{l}\mathrm{HZ-} \\
618\end{array}$ & $\begin{array}{l}5^{\prime} \text { AGT TCC AAG TTG CCC TGC } \\
\text { Tा } 3^{\prime}\end{array}$ & & & ORF8b & no match & 115 & 12.9 & 97.2 \\
\hline
\end{tabular}


their homologous sequences of MeCSV using CLUSTALW (Table 1) [10]. The genome components of JKI 29327 shared nt identities ranging from 68.7 to $85.8 \%$ with those of the MeCSV isolate E11-0188 (Table 1). The proteins potentially encoded by JKI 29327 and E11-018 shared aa sequence identities ranging from 80.6 to $97.2 \%$ (Table 1). A maximum-likelihood (ML) phylogenetic tree was generated using MEGA7 (7.0.26) (Jones-Taylor-Thornton (JTT) model) [11] for comparing the aa sequence of nucleocapsid proteins of JKI 29327 and other tenuiviruses. This showed a tight clustering of JKI 29327 with the MeCSV nucleoprotein (Fig. 2b). Additionally, RNA segments 7 and 8 respectively have shorter intergenic regions (IR) (586 and $446 \mathrm{nt}$ ) compared with those (680 and $623 \mathrm{nt}$ ) on the homologous RNAs of E11-018. The nt sequence identities between these IR regions of RNA7 and RNA8 are 55.6 and $58.3 \%$, respectively. The results indicate that JKI 29327 is closely related to but distinct from the MeCSV isolate E11-018.

For additional confirmation, purified RNP preparations of JKI 29327 were again examined by electron microscopy and shown to contain tenuivirus-like circular filamentous particles representing the individual genome segments (Fig. 3).

To assess the serological relationship between JKI 29327 and E11-018, N. benthamiana and Physalis floridana leaves infected with the MeCSV isolate E11-018 (kindly provided by Dr. C. Desbiez) were tested in DASELISA using the JKI 1608 antibodies to JKI 29327. The latter gave strong $\left(\mathrm{A}_{405} \mathrm{~nm}\right.$ values: > 2.0) reactions with JKI 29327 (in four different plant spp.) and intermediate reactions $\left(\mathrm{A}_{405} \mathrm{~nm}: 1.0\right.$ to 2.0$)$ with E11-018, indicating that the serological relationship between these two isolates is close. Additionally, JKI 29327 was mechanically inoculated to melon cv. Védrantais (kindly provided by
Dr. C. Desbiez). The plants showed chlorotic spots only on inoculated leaves and tested positive in DAS-ELISA with the JKI 1608 antibodies. Whilst JKI 29327 could be detected in inoculated leaves, no systemic infection was observed (data not shown).

The species demarcation criteria of ICTV for the genus Tenuivirus suggest that a new species should be considered when (i) the aa sequence identities between any corresponding gene products is below $85 \%$; (ii) the nt sequence identities between corresponding IRs is below 60\%; (iii) there are different sizes and/or numbers of genomic components; (iv) there are differences in host range; (v) the vectors are different [1]. For certain tenuiviruses, it has been difficult to decide whether they belong to the same or different species because all the five criteria are not always met [1]. For example, RHBV, EHBV and UHBV have different vectors, different hosts, different sizes and numbers of RNA segments and the nt sequence identity of their IR is $<60 \%$. Yet, the four protein homologs on their RNA3 and RNA4 are 90\% identical in aa sequences.

The black medic tenuivirus isolate JKI 29327 fulfils three out of these five criteria. Firstly, its ORF2 of RNA7 shares $80.6 \%$ aa identity with its homologue in the E11-081 genome. Secondly, the IRs of both RNA7 and RNA8 share < $60 \%$ nt identities with those of E11-081. Thirdly, the overall genome size of JKI 29327 is 247 nt shorter than that of E11081. Based on these three criteria, the black medic virus should be considered a new species. However, although the host range was not studied in full detail, both JKI 29327 and E11-081 infected members of the Fabaceae, the Cucurbitaceae and the Solanaceae families under experimental conditions. Moreover, these two isolates appear to be serologically closely related when tested with the JKI 1608 antibodies. Small differences in size, particularly in the intergenic regions, are common and can be observed between isolates of

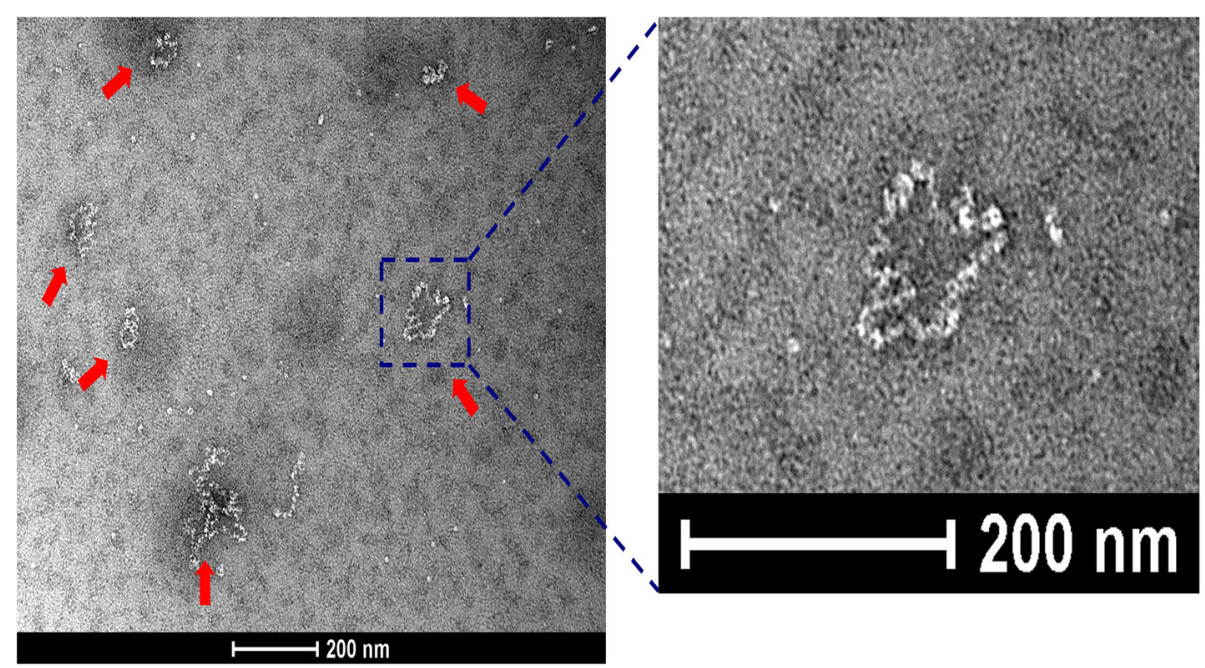

Fig. 3 Electron micrograph of a purified ribonucleoprotein preparation showing tenuivirus-like circular filamentous ribonucleoproteins (RNP) of different sizes (red arrows) 
RSV $[12,13]$. Also, segment RNA 7 of MeCSV E11-018 was shown to present size heterogeneity due to indels in the intergenic region [2]. Furthermore, only one protein out of 13 was below the $85 \%$ identity threshold. Therefore, we propose that the black medic isolate from Austria is a strain of MeCSV and is referred to accordingly as black medic strain of MeCSV. Further studies are required to identify possible natural hosts and insects that may act as vectors of both JKI 29327 and E11-081. Moreover, there is a need to compare the experimental and natural host ranges of the two MeCSV strains. The antiserum obtained in this study will help to monitor prevalence and geographic distribution of MeCSV as well as its agronomic impact on crop plants (e.g., melons, legumes). Furthermore, it is important to study the function of the virus proteins that have been predicted in silico.

\section{Abbreviations \\ aa: amino acid; DAS-ELISA: double antibody sandwich enzyme-linked im- munosorbent assay; EHBV: echinochloa hoja blanca virus; EM: electron microscopy; HTS: high throughput sequencing; ICTV: International Committee on Taxonomy of Viruses; IR: intergenic regions; JKI: Julius Kuehn Institute; MeCSV: melon chlorotic spot virus; ML: maximum-likelihood; MSpV: maize stripe virus; NCp: nucleocapsid protein; nt: nucleotide; RdRp: RNA-dependent RNA polymerase; RHBV: rice hoja blanca virus; RmSV: Ramu stunt virus; RNP: ribonucleoprotein; RSV: rice stripe virus; RT- PCR: reverse transcription polymerase chain reaction; UHBV: urochloa hoja blanca virus; WYHV: wheat yellow head virus}

\section{Acknowledgments}

The authors are grateful to Dr. Cecile Desbiez for kindly providing the samples infected with MeCSV (isolate E11-018) and seeds of melon cV. Védrantais. We are thankful to Carolin Heidler, Christina Maaß and Sabine Schuhmann for excellent technical support in serological analyses and electron microscopy.

\section{Authors' contributions}

YZAG and HZ conceived and designed the study; YZAG carried out molecular studies; KR-P performed the electron microscopy experiments; AS, $\mathrm{PL}, \mathrm{KH}, \mathrm{JH}$ and YS provided technical assistance; $\mathrm{H}$-JV provided the infectious material, initiated virus purification, and assisted in drafting the manuscript; YZAG analysed the data; YZAG drafted the manuscript; Funding was acquired by $\mathrm{HZ}$; all authors read and approved the final version.

\section{Funding}

This work was financially supported by the German Federal Ministry of Food and Agriculture (BMEL) through the Federal Office for Agriculture and Food (BLE), grant number 2815ERA02K (EUPHRESCO project "The application of Next-Generation Sequencing technology for the detection and diagnosis of non-culturable organism: Viruses and viroids"). Yahya Z. A. Gaafar was funded by the German Egyptian research long term scholarship. Open access publication was enabled by JKI core funding.

\section{Availability of data and materials}

Raw sequence data are available in the Sequence Read Archive (SRA) under BioSample accession number SAMN11974730, BioProject accession number PRJNA524397.

\section{Ethics approval and consent to participate}

The use of animals for antibody production was in accordance with the national legislation and was covered by the appropriate licenses.

\section{Consent for publication}

All authors agreed to the publication of this manuscript.

\section{Competing interests}

The authors declare that they have no competing interests.

\section{Author details}

Julius Kühn Institute, Institute for Epidemiology and Pathogen Diagnostics, Messeweg 11-12, 38104 Braunschweig, Germany. ${ }^{2}$ Im Spargelfeld 1, 38162 Cremlingen, Germany.

Received: 25 April 2019 Accepted: 24 June 2019

Published online: 05 July 2019

\section{References}

1. Shirako Y, Falk BW, Haenni AL, King AMQ, Adams MJ. Genus Tenuivirus. In: King AMQ, Adams MJ, Carstens EB, Lefkowitz EJ, editors. Virus taxonomy: ninth report of the international committee on taxonomy of viruses. Elsevier Academic Press San Diego; 2012. p. 771-776.

2. Lecoq H, Wipf-Scheibel C, Verdin E, Desbiez C. Characterization of the first tenuivirus naturally infecting dicotyledonous plants. Arch Virol. 2019;164: 297-301. https://doi.org/10.1007/s00705-018-4057-6.

3. Seifers DL, Harvey TL, Martin TJ, Haber S, She Y-M, Ens W, et al. Association of a virus with wheat displaying yellow head disease symptoms in the great plains. Plant Dis. 2005;89:888-95. https://doi.org/10.1094/PD-89-0888.

4. Mollov D, Maroon-Lango C, Kuniata L. Detection by next generation sequencing of a multi-segmented viral genome from sugarcane associated with Ramu stunt disease. Virus Genes. 2016;52:152-5. https://doi.org/10.1007/s11262-015-1279-5.

5. Falk BW, Tsai JH. Biology and molecular biology of viruses in the genus Tenuivirus. Annu Rev Phytopathol. 1998;36:139-63. https//doi.org/10.1146/annurev.phyto.36.1.139.

6. Iseni F, Barge A, Baudin F, Blondel D, Ruigrok RW. Characterization of rabies virus nucleocapsids and recombinant nucleocapsid-like structures. J Gen Virol. 1998;79 (Pt 12):2909-19. https://doi.org/10.1099/0022-1317-79-12-2909.

7. Gaafar YZA, Richert-Pöggeler KR, Maaß C, Vetten H-J, Ziebell H. Characterisation of a novel nucleorhabdovirus infecting alfalfa (Medicago sativa). Virol J. 2019;16:113. https://doi.org/10.1186/s12985-019-1147-3.

8. Untergasser A, Cutcutache I, Koressaar T, Ye J, Faircloth BC, Remm M, Rozen SG. Primer3--new capabilities and interfaces. Nucleic Acids Res. 2012;40: e115. https://doi.org/10.1093/nar/gks596.

9. Marchler-Bauer A, Bo Y, Han L, He J, Lanczycki CJ, Lu S, et al. CDD/SPARCLE: functional classification of proteins via subfamily domain architectures. Nucleic Acids Res. 2017:45:D200-3. https://doi.org/10.1093/nar/gkw1129.

10. Larkin MA, Blackshields G, Brown NP, Chenna R, McGettigan PA, McWilliam $H$, et al. Clustal W and Clustal X version 2.0. Bioinformatics. 2007;23:2947-8. https://doi.org/10.1093/bioinformatics/btm404

11. Kumar S, Stecher G, Tamura K. MEGA7: molecular evolutionary genetics analysis version 7.0 for bigger datasets. Mol Biol Evol. 2016;33:1870-4. https://doi.org/10.1093/molbev/msw054.

12. Lu L, Wu S, Jiang J, Liang J, Zhou X, Wu J. Whole genome deep sequencing revealed host impact on population structure, variation and evolution of Rice stripe virus. Virology. 2018:524:32-44. https://doi.org/10.1016/j.virol.2018.08.005.

13. Wei T-Y, Yang J-G, Liao F-R, Liao F-L, Gao F-L, Lu L-M, et al. Genetic diversity and population structure of rice stripe virus in China. J Gen Virol. 2009;90: 1025-34. https://doi.org/10.1099/vir.0.006858-0.

\section{Publisher's Note}

Springer Nature remains neutral with regard to jurisdictional claims in published maps and institutional affiliations.
Ready to submit your research? Choose BMC and benefit from:
- fast, convenient online submission
- thorough peer review by experienced researchers in your field
- rapid publication on acceptance
- support for research data, including large and complex data types
- gold Open Access which fosters wider collaboration and increased citations
- maximum visibility for your research: over $100 \mathrm{M}$ website views per year
At $\mathrm{BMC}$, research is always in progress.
Learn more biomedcentral.com/submission 